\title{
MENCIPTAKAN KEUNGGULAN DAYA SAING WILAYAH MELALUI PEMBANGUNAN BERKELANJUTAN
}

\author{
Syukrianti Mukhtar
}

\begin{abstract}
Abstrak
Berbagai upaya untuk menciptakan keunggulan daya saing suatu wilayah tidak pernah berhenti dan terus menghasilkan pendekatan - pendekatan baru dalam konsep pengembangan wilayah. Pendekatan yang menjadi state of the art dari konsep pengembangan wilayah dewasa ini adalah pendekatan pembangunan yang mengarah pada penciptaan keunggulan daya saing wilayah yang berkelanjutan. Upaya ini menuntut adanya perubahan paradigma dalam membangun suatu wilayah. Diantaranya adalah dengan meningkatkan aksesibilitas suatu wilayah terhadap penciptaan dan peningkatan peranan teknologi. Gagasan mengenai konsep pengembangan wilayah berbasis teknologi (Technology Based Regional Development) muncul sejak adanya pergeseran paradigma dalam pengembangan suatu wilayah, yaitu dari konsep pengembangan wilayah yang semula mengandalkan sumber-sumber keunggulan komparatif (Comparative Advantage) menuju kepada konsep pengembangan wilayah yang mengarah pada penciptaan keunggulan daya saing (Competitive Advantage). Trilogi pembangunan yang selama ini dijadikan pedoman dasar dalam pola dan arah pembangunan kita (pertumbuhan, pemerataan, kestabilan) kini mengandung dimensi tambahan dalam arti bahwa trilogi pembangunan harus ditempatkan dalam rangka pembangunan yang berkelanjutan. Indonesia merupakan salah satu negara yang telah memelopori kebijakan strategi dalam hal pembangunan yang berkelajutan. Pemerintah telah menggariskan beberapa ciri pokok dalam kebijakan negara untuk mendukung strategi pembangunan yang berkelajutan. Selain itu ditetapkan langkah-langkah kebijakan di berbagai bidang tertentu yang berkenaan dengan masalah lingkungan hidup. Namun tidak dapat disangkal bahwa masih banyak yang harus dilakukan, terutama mengenai pelaksanaan efektif perubahan perundang-undangan dan ketentuan dalam rangka kebijakan yang telah ditentukan itu. Berdasarkan pengalaman pembangunan selama ini, menonjolkan beberapa kelompok permasalahan yang harus terus dipantau dan diperhatikan dalam perkembangan dimasa datang: (1). Pembangunan akan semakin ditandai oleh perkembangan industri. Hal ini harus mengandalkan berbagai jenis sumberdaya alam yang mendasar, pemanfataan, pengamanan, dan pemeliharaan sumber daya alam merupakan tiga dimensi yang tidak terlepas satu dari yang lainnya dalam rangka kebijakan pembangunan yang berkelanjutan. (2). Sebagai akibat perkembangan industri dan transportasi, kita akan menghadapi bahaya pencemaran di kota-kota besar. Hal itu akan membahayakan kesehatan manusia dan masyarakat pada umumnya. (3). Masalah keadilan dalam memikul beban biaya untuk menanggulangi kerusakan sumber daya alam dan pencemaran kota-kota menjadi masalah sosial politik.
\end{abstract}

Kata Kunci: Pengembangan wilayah, keunggulan daya saing wilayah, strategi pembangunan yang berkelanjutan (sustainable development).

Intensitas persaingan antar wilayah (Interregional Competition) yang

semakin tinggi merupakan salah satu fenomena yang menjadi ciri utama dinamika perekonomian global pada bad yang ke 21. Di Indonesia persaingan antar wilayah diperkirakan akan berlangsung antar daerah otonomi, terutama level

jsh Jurnal Sosial Humaniora, Vol 5 No.2, November 2012 
kabupaten/kota. Sejak Januari 2001 kebijakan otonomi daerah di Indonesia telah memasuki tahap implementasi. Daerah otonomi yang miskin sumber daya alam, SDM, dan teknologi lebih dikenal dengan sebutan tiga pilar pengembangan wilayah akan berupaya keras melaksanakan berbagai strategi untuk meningkatkan daya saingnya. Tujuan utamanya adalah agar tidak tenggelam diantara daerah otonomi yang memiliki SDA, SDM, dan teknologi yang kompetitif.

Sementara itu ditingkat global sedikitnya terdapat tiga fenomena yang berperan dalam peningkatan intensitas persaingan antar wilayah. Ketiganya adalah tren perdagangan global, kemajuan teknologi dan perubahan sistem kemasyarakatan.

Pertama, tren perdagangan global (Global Trade) menciptakan pasar dunia yang luasnya berlipat-lipat dibandingkan pangsa pasar sebelumnya. Globalisasi yang ditandai dengan berkembang biaknya kawasan ekonomi maupun kawasan perdangangan bebas (Free Trade Area) akan berdampak pada kegiatan ekonomi di seluruh dunia.

Kedua, kemajuan teknologi (Technology Progress) hingga akhir abad ke 20 telah pula merubah dunia menjadi lebih dinamis. Teknologi telah memungkinkan berbagai negara maupun perusahaan mampu meningkatkan daya saing melalui (ICS-UNIDO:15):

- biaya produksi yang lebih efisien;

- harga yang bersaing;

- jenis produk yang lebih bervariasi;

- model yang sering berubah dan desain yang lebih maju ;

- $\quad$ kualitas produk yang lebih tinggi;

- pelayanan yang lebih baik ;

- transportasi yang lebih cepat ;

- produk yang lebih memenuhi selera konsumen.

Ketiga, dalam sistem kemasyarakatan (Sociaty System), telah terjadi perubahan mendasar yang ditandai dengan meningkatkannya kesadaran akan kebebasan (demokrasi), kemandirian (otonomi), keterbukaan (transparansi) dan kreatifitas (inovasi) masyarakat. 


\section{Konsep Pengembangan Wilayah}

Pertumbuhan ekonomi yang tinggi, pendapatan per kapita yang merata, dan tingkat pengangguran yang rendah merupakan tolak ukur utama bagi kemajuan pembangunan suatu wilayah. Sedangkan tolak ukur lainnya seperti stabilitas politik, kepastian hukum, kelembagaan sosial, budaya, dan kelestarian lingkungan hidup berperan untuk menjamin kesinambungan kemajuan dan pemerataan dari waktu ke waktu.

Dalam kontek Indonesia, adanya kesenjangan pembangunan antar wilayah telah menyebabkan tidak tercapainya salah satu trilogi pembangunan nasional, yaitu pemerataan pembangunan dan hasil-hasilnya. Karena itu, kesadaran akan perlunya perencanaan wilayah menjadi bagian dari perencanaan pembangunan nasional hingga kini terus berkembang. Disadari bahwa pengembangan wilayah tidak hanya meningkatkan pertumbuhan ekonomi, tetapi merupakan suatu proses perbaikan tatanan sosial, ekonomi, hukum, politik, lingkungan hidup, dan kesejahteraan masyarakat yang langgeng (sustainable welfare). Tujuan tersebut dapat dicapai apabila wilayah bersangkutan mempunyai kondisi yang dinamis untuk menghadapi persaingan.

Oleh karena itu meskipun konsep pengembangan wilayah telah banyak dibahas dan dikembangkan, namun konsep pembangunan pada suatu wilayah harus tetap mengacu pada kondisi wilayah itu sendiri (inward looking). Pemilihan prioritas pembangunan yang mengacu pada kebutuhan masyarakat dalam bidang ekonomi, sosial, hukum, politik, dan bidang-bidang lainnya merupakan keharusan yang tidak dapat diabaikan apabila kesejahteraan masyarakat yang diutamakan. Konsep pembangunan dengan berbagai dimensi yang diterapkan pada suatu wilayah sering menemukan kenyataan bahwa konsep tersebut memerlukan modifikasi atau penyesuaian kearah karakteristik lokal.

Pengembangan pada umumnya mencakup berbagai dimensi pembangunan yang dilaksanakan secara bertahap. Pada tahap awal kegiatan pengembangan wilayah biasanya ditekankan pada pembangunan fisik untuk mendorong pertumbuhan ekonomi, kemudian diikuti dengan pembangunan sistem sosial dan politik. Namun begitu, tahapan ini bukanlah merupakan suatu ketentuan 
yang baku, karena setiap wilayah mempunyai potensi pertumbuhan yang berbeda dengan wilayah lainnya. Potensi SDA, kondisi sosial, budaya, ekonomi masyarakat, ketersediaan infrastruktur, dan lainnya sangat berpengaruh pada penerapan konsep pengembangan wilayah yang digunakan.

Secara garis besar, berikut ini dapat dikemukakan beberapa konsep konvensional tentang pengembangan wilayah (Komet Mangiri, 2000:65-84: Ati Widiati,2000;48-49).

\section{Pengembangan Wilayah Berbasis Sumber Daya}

Konsep pengembangan wilayah berbasis sumber daya ini terdapat pilihan strategi yakni:

a. Pengembangan wilayah berbasis input, tetapi surplus sumber daya manusia

b. Pengembangan wilayah berbasis input, tetapi surplus sumber daya alam

c. Pengembangan wilayah berbasis sumber daya modal dan manajemen

d. Pengembangan wilayah berbasis seni, budaya, dan keindahan alam

e. Pengembangan wilayah berbasis penataan ruang (lokasi strategis)

\section{Pengembangan Wilayah Berbasis Komoditas Unggulan}

Ada beberapa kreteria mengenai komoditas unggulan, diantaranya :

a. Komoditas unggulan harus mampu menjadi penggerak utama (primer mover) pembangunan perekonomian

b. Komoditas unggulan mempunyai keterkaitan ke depan dan ke belakang (forward dan backward linkages) yang kuat, baik sesama komoditas unggulan maupun komoditas-komoditas lainnya.

c. Komoditas unggulan mampu bersaing dengan produk sejenis dari wilayah lain (Competitiveness) di pasar nasional maupun pasar internasional, baik dalam harga produk, biaya produksi, maupun kualitas pelayanan.

d. Komoditas unggulan di suatu wilayah memiliki keterkaitan dengan wilayah lain (Complementarity) baik dalam hal pasar (konsumen) maupun pemasokan bahan baku (jika bahan baku di wilayah sendiri tidak mecukupi atau tidak tersedia sama sekali). 
e. Komoditas unggulan memiliki status teknologi (state-of-the-art) yang terus meningkat, terutama melalui inovasi teknologi.

f. Komoditas unggulan mampu menyerap tenaga kerja berkualitas secara optimal sesuai dengan skala produksinya.

g. Komoditas unggulan bisa bertahan dalam jangka waktu tertentu, mulai dari fase kelahiran (increasing), pertumbuhan (growth), hingga fase kejenuhan (maturity) atau penurunan (decreasing). Begitu Komoditas unggulan yang satu memasuki tahap kejenuhan/penurunan, maka Komoditas unggulan lainnya harus mampu menggantikannya.

h. Komoditas unggulan tidak rentan terhadap gejolak eksternal dan internal.

i. Pengembangan Komoditas unggulan harus mendapatkan berbagai bentuk dukungan misalnya keamanan, sosial, budaya, informasi, dan peluang pasar, kelembagaan, fasilitas intensif/disintensif dan lainnya.

j. Pengembangan Komoditas unggulan berorientasi pada kelestarian sumber daya dan lingkungan.

\section{Pengembangan Wilayah Berbasis Efisiensi (Free Market Mechanism)}

Konsep ini menekankan pengembangan wilayah melalui pembangunan bidang ekonomi yang porsinya lebih besar dibandingkan bidang-bidang lainnya. Pembangunan ekonomi itu sendiri dijalankan dalam kerangka pasar bebas atau pasar persaingan sempurna.

Strategi pengembangan wilayah yang bertumpu pada prinsip efisiensi merupakan pilihan yang cukup sulit bagi para perencana pembangunan (Planer) maupun pengambil keputusan (decision maker). Tidak jarang sebuah wilayah pada awalnya mampu menerapkan prinsip efisiensi, tetapi pada perjalanan selanjutnya terpaksa prinsip tersebut harus ditinggalkan. Ada beberapa pedoman yang perlu diperhatikan dalam menyusun strategi efisiensi ini, diantaranya :

a. Mengacu pada visi dan misi pembangunan wilayah yang bersangkutan serta visi dan misi pembangunan di wilayah yang lebih luas.

b. Mengacu pada kapabilitas sumber daya yang dimiliki dan tetap berorientasi pada pelaksanaan misi dan pencapaian visi pengembangan wilayah itu. 
c. Memperhitungkan secara akurat jangka waktu yang diperlukan untuk pencapaian visi dan misi. Semakin kuat kapabilitas sumber daya semakin cepat waktu (tahapan) yang dibutuhkan untuk pencapaian visi dan misi.

d. Mengacu pada prioritas kebutuhan masyarakat di wilayah yang bersangkutan.

\section{Pengembangan Wilayah Menurut Pelaku Pembangunan}

Strategi pengembangan wilayah dapat pula ditempuh dengan mengedepankan peranan pelaku pembangunan nasional. Menurut United Nations (1968), pelaku pembangunan ekonomi dipilah menjadi lima kelompok, yaitu :

a. Usaha kecil/rumah tangga (household), seperti petani, nelayan, pedagang dan usaha kecil/rumah tangga lainnya.

b. Usaha lembaga sosial (nonprofil institution) seperti pendidikan, rumah sakit, lembaga keagamaan, dan usaha lembaga sosial lainnya.

c. Lembaga bukan keuangan (nonfinancial institution) seperti usaha pertambangan, perkebunan, industri tekstil, semen, mobil, dan berbagai bentuk usaha di sektor riil lainnya.

d. Lembaga keuangan (financial institution) seperti bank, asuransi, pegadaian, pasar modal, dan lembaga keuangan lainnya.

e. Pemerintah (government) baik pemerintah pusat maupun pemerintah daerah, melalui BUMN dan BUMD.

Di Indonesia disamping kelima pelaku pembangunan ekonomi diatas, dapat pula ditambahkan satu lagi pelaku pembangunan ekonomi lainnya yang mempunyai dasar hukum sangat kuat sebagaimana tercatum dalam UndangUndang Dasar 1945, yaitu koperasi.

Meskipun berbeda pendekatan konsep-konsep pengembangan wilayah sebagaimana telah diuraikan diatas sama-sama memuat dua aspek pembahasan, yakni materi yang bersifat sektoral dan materi yang bersifat spasial (keruangan). Kajian sektoral merupakan perwujudan dan trasformasi sumber daya alam yang berlangsung dalam suatu wilayah dalam skala yang rinci. Antara lain menyangkut jenis, input, output, produktifitas, kapasitas, pertumbuhan, dan perkembangan aktifitas masyarakat di suatu wilayah. Dengan kata lain, kajian sektoral 
merupakan kajian yang menyatakan ukuran dari aktifitas masyarakat suatu wilayah dalam mengolah sumber daya yang dimilikinya.

Sementara aspek spasial merupakan kajian yang menunjukkan arah (direction) dari kegiatan sektoral, sehingga lebih merupakan jawaban dari pertanyaan dimana aktifitas masyarakat berlangsung, kearah mana aktifitas berkembang secara optimal.

Dalam kontek pengkajian pengembangan wilayah, kedua aspek diatas merupakan satu kesatuan. Pembagian materi ke dalam dua aspek tersebut hanya dimaksudkan untuk memudahkan dalam penyusunan dan pencarian data-data maupun indikator-indikator yang dibutuhkan.

\section{Konsep Penataan Ruang dalam Pengembangan Wilayah}

Penataan ruang mempunyai tiga tujuan. Pertama, meningkatkan efisiensi penggunaan ruang sesuai dengan daya dukungnya. Kedua, memberikan kesempatan kepada masing-masing sektor untuk berpartisipasi dan berkembang secara maksimal tanpa adanya konflik. Ketiga, meningkatkan kesejahteraan masyarakat secara merata. Dengan demikian walaupun bersifat spasial, perencanaan tata ruang harus didukung oleh kebijakan-kebijakan sektoral, misalnya kebijakan transportasi, pertanian, industri, perdagangan, kesehatan, pendidikan, dan lain-lain agar secara efektif dapat mendorong peningkatan kemajuan ekonomi di seluruh wilayah.

Ada tiga konsep utama pengembangan wilayah yang didasarkan pada penataan ruang, yaitu : Pusat Pertumbuhan, konsep pusat pertumbuhan (growth pole) menekankan pada perlunya melakukan investasi secara besar-besaran pada suatu wilayah yang telah mempunyai infrastruktur yang cukup baik. Hal ini dimaksudkan untuk menghemat investasi prasarana dasar dengan harapan perkembangan sektor unggulan tersebut akan menarik penanaman modal dalam jumlah yang lebih besar. Adapun pengembangan wilayah di sekelilingnya diharapkan diperoleh melalui proses tetesan ke bawah (trickle down effect). Integrasi Fungsional, integrasi fungsional (fungtional integration) adalah suatu alternatif pendekatan yang mengutamakan adanya integrasi yang diciptakan 
secara sengaja diantara berbagai pusat pertumbuhan karena adanya fungsi yang komplementer. Konsep ini menempatkan suatu kota atau wilayah mempunyai hirarchi- misalnya sebagai pusat pelayanan- terhadap kota atau wilayah yang lain. Perencanaan kota di Indonesia banyak menganut konsep ini, namun integrasi yang dilakukan bukan didasarkan pada potensi produksi, tetapi lebih pada fungsi administrasi pemerintahan. Misalnya ibukota propinsi mempunyai hirarchi sebagai pusat pelayanan yang lebih tinggi dibandingkan ibukota kabupaten. Desentralisasi, pendekatan desentralisasi (decentralization approach) dimaksudkan untuk mencegah tidak terjadinya aliran keluar (outflow) dari sumber daya modal dan sumber daya manusia (brain drain). Aliran keluar ini sangat merugikan wilayah-wilayah yang selama ini dianggap terbelakang, seperti Kawasan Timur Indonesia (KTI).

\section{Konsep Kebijakan Sektoral dan Pendekatan Terpadu}

Disamping konsep pengembangan wilayah melalui penataan ruang, kebijakan sektoral sangat perperan dalam mencapai sasaran pembangunan suatu wilayah. Kebijakan yang tidak tepat dapat menghilangkan arti dari suatu perencanaan wilayah. Hal seperti ini dapat disimak dari konsep pembangunan Indonesia dimasa lalu. Kesenjangan antara pulau Jawa dan luar pulau Jawa terjadi akibat kebijakan sektoral yang tidak kondusif sebagai kemajuan pertumbuhan ekonomi luar pulau Jawa, baik kebijakan di sektor perindustrian, perdagangan, perhubungan, kehutanan, pertambangan, maupun sektor-sektor lainnya.

Ada beberapa konsep yang sering dikemukakan untuk menanggapi kelemahan pendekatan sektoral. Antara lain konsep people centre approach yang menekankan pada pembangunan sumber daya manusia dan konsep natural resources-based development yang mengandalkan sumber daya alam sebagai modal pembangunan. Sedangkan konsep technology-based (regional) development yang melihat bahwa teknologi merupakan kunci dari keberhasilan pembangunan (wilayah) belum banyak dibicarakan, apalagi diterapkan. 


\section{Struktur dan Proses Pertumbuhan Wilayah}

Pemahaman terhadap struktrur dan proses pertumbuhan wilayah sangat penting bagi perencana maupun pengmabil keputusan. Melalui pemahaman tersebut, suatu perencanaan dapat dituangkan secara lebih realistis dan berpihak pada kepentingan kewilayahan. Pertumbuhan wilayah merupakan suatu proses yang dihasilkan oleh dinamika perkembangan internal dan eksternal wilayah tersebut, baik ekonomi, sosial, maupun politik.

Dalam sejarah pembangunan negara-negara industri maju, kebijakan kewilayahan (Regional Policy) merupakan fungsi dari transformasi spasial yang diakibatkan oleh pertumbuhan ekonomi nasional. Di Indonesia, pada tahap awal pembangunan (Pelita I), sumbangan sektor pertanian masih dominan. Akibatnya kebijakan spasial tidak memperoleh perhatian cukup. Semua kemampuan nasioanl diarahkan pada penataan sektor pertanian, pemenuhan kebutuhan dasar,peningkatan sumber daya manusia, dan pembangunan infrastruktur dasar. Wilayah-wilayah kecil yang didomiasni oleh kegiatan pertanian pada umumnya tidak terlalu tinggi tingkat ketergantungan pada wilayah disekitarnya.

Akan tetapi ketika sektor manufaktur dan jasa mulai memberikan sumbangan cukup besar kepada produksi nasional, maka kesenjangan muncul akibat infrastruktur ekonomi yang lebih modern pada kota-kota besar tidak dimanfaatkan secara optimal oleh kalangan yang bergerak pada sektor pertanian (traditional sector). Pusat-pusat pertumbuhan yang mempunyai berbagai infrastruktur, berkembang dengan cepat dan menyedot sebagian besa investasi. Sedangkan wilayah sekitarnya yang luas menjadi daerah pinggiran dengan pertumbuhan yang rendah, malah ada yang negatif, sehingga muncul dua struktur ekonomi yang kontras antara pusat yang tumbuh menakjubkan dan daerah pinggiran (periphery) yang stagnan atau bahkan ada yang menurun.

Model centre-periphery adalah gejala wajar pada tingkat awal pertumbuhan wilayah, dan beberapa pakar percaya bahwa secara alamiah akan terjadi aliran kemajuan dari pusat kepinggiran yang di sebut dengan tricle down effect. 


\section{Menuju Paradigma Baru Pengembangan Wilayah di Indonesia}

Dengan semakin kompleknya fenomena yang dihadapi bangsa Indonesia di masa-masa mendatang, baik berupa perubahan-perubahan internal maupun eksternal, maka dapat dibayangkan bahwa untuk mengelola pembangunan 33 provinsi dan 400-an kabupaten/kota (2010) secara terpusat sungguhlah amat sulit. Pengalaman selama ini menunjukkan bahwa sistem pembangunan terpusat telah gagal menghasilkan keseimbangan kemajuan pembangunan antar wilayah. Karena itu, pilihan yang paling tepat adalah dengan memberikan kewenangan yang lebih besar kepada daerah untuk mengelola pembangunan di wilayahnya sendiri. Pilihan ini sudah dijatuhkan oleh pemerintah pusat dalam bentuk otonomi daerah di tingkat kabupaten/kota dan desa (Undang-undang nomor 22 tahun 1999). Sejak Januari 2001, era otonomi daerah di Indonesia sudah dimulai. Dengan kewenangan yang lebih besar diharapkan pendekatan desentralisasi dapat menghasilkan pola pengembangan wilayah yang sesuai dengan karakteristik sumber daya alam, sumber daya manusia, dan teknologi yang dimiliki, sehingga pengembangan wilayah dapat berlangsung dalam situasi persaingan yang sehat dan kuat.

Meskipun sudah mendapat kewenangan yang cukup luas dalam membangun wilayahnya sendiri, akan tetapi hingga kini - setelah era otonomi daerah berjalan sekian tahun - diperkirakan masih banyak kabupaten/kota yang belum mampu merumuskan visi dan misi, strategi, kebijakan, maupun program seperti apa yang akan ditempuh untuk meningkatkan daya saingnya, baik dalam percaturan persaingan domestik maupun global. Bahkan diperkirakan masih banyak pula kabupaten/kota yang belum tahu, bagaimana caranya mengelola infrastruktur yang mereka miliki, serta bagaimana mengelola perubahanperubahan (peluang dan tantangan) global. Ini baru pertanyaan mengenai how, belum berkaitan dengan what, who, why, when, dan where. Ketergantungan pada pola sentralistis yang diterapkan selama puluhan tahun ternyata masih menjerat mereka. Apabila kondisi seperti ini tidak segera diatasi, maka cepat atau lambat akan banyak kabupaten/kota yang terancam "tenggelam" di dalam ketidakberdayaan. 
Untuk menghindari ancaman tersebut, maka sejak dini seluruh pemerintah daerah otonom di Indonesia bersama dengan pemerintah pusat dan provinsi serta para pelaku pembangunan lainnya, harus mampu menemukan konsep yang paling tepat dan mampu mengantarkan daerahnya pada persaingan domestik maupun global. Bagaimanapun, konsep pembangunan yang berorientasi pada keunggulan daya saing akan menjadi paradigma baru dalam pengembangan wilayah dimasa mendatang.

Di dalam paradigma baru itu, wilayah dianalogkan sebagai suatu perusahaan besar yang memiliki elemen-elemen pokok yang saling terkait. Suatu wilayah dipandang sebagai sistem yang terdiri dari eleme-elemen yang saling berinteraksi. Seperti telah dikemukakan sebelumnya, elemen pokok yang membentuk sistem wilayah antara lain sumber daya alam, sumber daya manusia, dan teknologi. Secara alamiah,ketiga elemen tersebut berinteraksi membentuk sistem transformasi input menjadi output dengan jenis yang berbeda-beda (sektorsektor ekonomi). Selanjutnya akumulasi dari trasformasi-transformasi tersebut menghasilkan kinerja pertumbuhan wilayah secara menyeluruh. Keterkaitan antara elemen dan proses transformasi yang akan dilalui suatu wilayah menurut cara pandang baru ini dapat dilihat pada table 1.1. Tabel tersebut memperlihatkan bahwa suatu sistem wilayah memiliki tingkatan-tingkatan yang bersifat hirarhi dalam proses perkembangan masyarakatnya.

Pendekatan yang relative baru dan menjadi salah satu state-of-the-art dari konsep pengembangan wilayah dewasa ini adalah pendekatan pembangunan yang mengarah pada penciptaan keunggulan daya saing yang berkelanjutan (sustainable regional competitive advantage). Upaya menuntut adanya suatu perubahan paradigma dalam membangun suatu wilayah, diantaranya adalah dengan meningkatkan aksesibilitas wilayah terhadap perubahan teknologi, sehingga muncullah pendekatan baru yang di sebut technology based regional development.

Sebagai ilustrasi perbedaan antara konsep pengembangan wilayah berbasis teknologi dan konsep pengembangan wilayah yang bersifat konvensional dapat dilihat pada Tabel 1. 
Tabel 1. Indikator-indikator Pengembangan Wilayah Menurut Konsep Perencanaan Pembangunan yang Konvensional dan Berbasis Teknologi

\begin{tabular}{|c|c|}
\hline Indikator Konvensional & Indikator Berbasis Teknologi \\
\hline \multicolumn{2}{|c|}{ 1.Analisis pada Tingkat Perusahaan } \\
\hline $\begin{array}{l}\text { - Aspek yang dikaji aspek produksi } \\
\text { - Indikator yang diukur: } \\
\text { - Faktor-faktor Produksi } \\
\text { - Lahan } \\
\text { - Tenaga kerja } \\
\text { - Modal / kapital }\end{array}$ & $\begin{array}{l}\text { - Aspek yang dikaji aspek transformasi } \\
\text { - Indikator yang diukur : } \\
\text { - Faktor-faktor transformasi } \\
\text { - Ketersediaan SDA } \\
\text { - Kemampuan SDM } \\
\text { - Tatanan organisasi } \\
\text { - Infrastruktur fisik } \\
\text { - Sistem informasi }\end{array}$ \\
\hline $\begin{array}{l}\text { - Ukuran produktivitas } \\
\text { - Produktivitas tenaga kerja } \\
\text { - Produktivitas modal }\end{array}$ & $\begin{array}{l}\text { - Ukuran kontribusi } \\
\text { - Kontribusi technoware (T) } \\
\text { - Kontribusi humanware }(\mathrm{H}) \\
\text { - Kontribusi inforware }(\mathrm{I}) \\
\text { - Kontribusi Orgaware }(\mathrm{O})\end{array}$ \\
\hline $\begin{array}{l}\text { - Ukuran kekuatan : Modal } \\
\text { - Tingkat bunga, inflasi, penyusutan } \\
\text { lainnya. }\end{array}$ & $\begin{array}{l}\text { - Ukuran kekuatan : Tingkat kemutahitran } \\
\text { teknologi } \\
\text { - Terobosan baru teknologi, kinerja, } \\
\text { konservasi, lainnya. }\end{array}$ \\
\hline $\begin{array}{l}\text { - Ukuran Matematis: analisis kelayakan } \\
\text { ekonomi } \\
\text { - IRR (internal rate of return) } \\
\text { - NPV (ner present value) } \\
\text { - BCR (benefit cost ratio) }\end{array}$ & $\begin{array}{l}\text { - Ukuran Matematis: analisis kontribusi } \\
\text { teknologi } \\
\text { - THIO } \\
\text { - TCC (technology contribution } \\
\text { coefficient) } \\
\text { TAC (technology concent added) }\end{array}$ \\
\hline \multicolumn{2}{|c|}{ 2. Analisis pada Tingkat Industri } \\
\hline $\begin{array}{l}\text { - Aspek yang dikaji output ekonomi } \\
\text { - Indikator yang diukur : } \\
\text { - Penggunaan kapasitas } \\
\text { - Rasio output-kapasitas } \\
\text { - Rasio kapital-output } \\
\text { - Lainnya } \\
\text { - Ukuran situasi Pasar } \\
\text { - Produksi dan konsumsi } \\
\text { - Volume ekspor impor }\end{array}$ & $\begin{array}{l}\text { - Aspek yang dikaji kandungan teknologi } \\
\text { - Indikator yang diukur : } \\
\text { - Status teknologi : } \\
\text { - Potensi THIO } \\
\text { - Peluang pengembangan THIO } \\
\text { - Kondisi THIO sekarang } \\
\text { - Sebaran produksi dan inovasi } \\
\text { - Ukuran situasi kandungan teknologi } \\
\text { - Kandungan impor input dan teknologi } \\
\text { - Kandungan ekspor output dan teknologi }\end{array}$ \\
\hline Indikator Konvensional & Indikator Berbasis Teknologi \\
\hline $\begin{array}{l}\text { - Ukuran pertumbuhan: peningkatan output } \\
\text { - Nilai tambah industri (value added, VA) } \\
\text { - Aspek kuantitatif produksi } \\
\text { - Peningkatan jenis dan kuantitas pekerja }\end{array}$ & $\begin{array}{l}\text { - Ukuran pertumbuhan: peningkatan } \\
\text { kemampuan teknologi } \\
\text { - Nilai tambah kandungan teknologi } \\
\text { - Aspek kuantitatif produksi } \\
\text { - Peningkatan jenis dan jumlah inovasi }\end{array}$ \\
\hline \multicolumn{2}{|c|}{ 3. Analisis pada Tingkat Sektoral } \\
\hline $\begin{array}{l}\text { - Aspek yang dikaji struktur ekonomi } \\
\text { - Indikator yang diukur } \\
\text { - Kontribusi sektoral terhadap PDB: }\end{array}$ & $\begin{array}{l}\text { - Aspek yang dikaji struktur teknologi } \\
\text { - Indikator yang diukur: } \\
\text { - Kontribusi tahapan transformasi terhadap }\end{array}$ \\
\hline
\end{tabular}




\begin{tabular}{|c|c|}
\hline $\begin{array}{l}\text { - Kontribusi sektor pertanian } \\
\text { - Kontribusi sektor industri } \\
\text { - Lainnya. } \\
\text { - Perubahan rsio kapital-output } \\
\text { - Dinamika ekonomi menurut sektoral } \\
\text { - Perubahan kontribusi relatif terhadap } \\
\text { PDB } \\
\text { - Perubahan struktur tenaga kerja }\end{array}$ & $\begin{array}{l}\text { TCA : } \\
\text { - Kontribusi tahapan cocok tanam } \\
\text { - Kontribusi tahapan pengolahan } \\
\text { - Lainnya. } \\
\text { - Perubahan tahapan TCC } \\
\text { - Dinamika transformasi teknologi } \\
\text { - Perubahan tahapan kandungan teknologi } \\
\text { - Perubahan tahapan angkatan kerja }\end{array}$ \\
\hline \multicolumn{2}{|c|}{ 4. Analisis pada Tingkat Nasional } \\
\hline $\begin{array}{l}\text { - Aspek yang dikaji dimensi ekonomi } \\
\text { - Indikator yang diukur } \\
\text { - Besaran ekonomi: GNP, GDP } \\
\text { - Status perkembangan: pendapatan per } \\
\text { kapita } \\
\text { - Matrik input-output } \\
\text { - Pertumbuhan ekonomi } \\
\text { - Distribusi pendapatan } \\
\text { - Harga bayangan (biaya opportunity) } \\
\text { - Neraca perdagangan }\end{array}$ & $\begin{array}{l}\text { - Aspek yang dikaji dimensi teknologi } \\
\text { - Indikator yang diukur: } \\
\text { - Besaran teknologi: TCA, PCT } \\
\text { - Status perkembangan: kemampuan } \\
\text { teknologi } \\
\text { - Matrik alir tekonologi } \\
\text { - Pertumbuhan kandungan teknologi } \\
\text { - Distribusi kandungan teknologi } \\
\text { - Faktor iklim (kerugian kesempatan) } \\
\text { - Neracapembayaran untuk teknologi } \\
\text { - Profil sumber daya dan infrastruktur } \\
\text { - Perencanaan komponen teknologi } \\
\text { - Technoware yang dibutuhkan } \\
\text { - Humanware yang dibutuhkan } \\
\text { - Inforware yang dibutuhkan } \\
\text { - Orgaware yang dibutuhkan }\end{array}$ \\
\hline \multicolumn{2}{|c|}{ 5. Strategi Pengembangan } \\
\hline $\begin{array}{l}\text { - Substitusi impor } \\
\text { - Orientasi ekspor atau promosi ekspor }\end{array}$ & $\begin{array}{l}\text { - Membuat dan atau membeli teknologi } \\
\text { - Impor dan atau ekspor teknologi }\end{array}$ \\
\hline
\end{tabular}

Sumber data: Alkadri (2008)

Perbedaan diantara kedua konsep dalam table 1.1 diatas pada dasarnya bukan merupakan sesuatu yang perlu dipertentangkan. Namun lebih tepat jika dipandang sebagai suatu yang saling melengkapi. Dalam konteks pengembangan wilayah kesulitan akan ditemukan bila pilihan analisis hanya didasarkan pada satu pendekatan saja. Hal ini dikarenakan proses pengembangan wilayah adalah suatu proses yang komplek dan dinamis, sehingga perlu suatu pendekatan yang memiliki dimensi luas, tidak saja pada satu aspek kajian tetapi lebih pada multi aspek. Untuk itu, integrasi diantara kedua konsep diatas merupakan alternatif terbaik bagi pengembangan wilayah di Indonesia pada abad ke 21 ini. 


\section{Daftar Pustaka}

Alkadri, 2008, "Dampak Utang Luar Negeri Terhadap Pertumbuhan Ekonomi dan Tabungan Domestik di Indonesia: Kajian 1969 - 2006, “Thesis Universitas Padjajaran, Bandung.

Alkadri, Muchdie, dan Suhandoyo, 1999, Tiga Pilar Pengembangan Wilayah: Sumber Daya Alam, Sumberdaya Manusia, dan Teknologi, Penerbit Direktorat Kebijaksanaan Tekonologi untuk Pengembangan Wilayah, BPPT, Jakarta.

Andi Makmur Makka, 2003, Pembangunan Berdasarkan Nilai Tambah dengan Orientasi Teknologi dan Industri: Gagasan dan Ulasan "Habibienomics", Teknotama Arya Kreasi, Jakarta.

Ati Widiati, 2000, “ Strategi Pengembangan Komoditas Unggulan Kota Pontianak Berorientasi Pembangunan Berkelanjutan, “Jurnal Sains dan Teknologi Indonesia, Vol.2 No.4 Juli, hlm 47-57.

Badan Koordinasi Tata Ruang Nasional, 1996, Rencana Tata Ruang Wilayah Nasional: Lampiran PP No. 47 (Draf).

Faried Harianto, 2003, "Perkembangan Teknologi: Kajian Teori," Makalah dalam Seminar Sehari Teknologi Dalam Perspektif Ekonomi, PEP-LIPI, Jakarta.

International Centre for Science and High Technology (ICS) and United Nations for Industrial development Organization (UNIDO), tanpa tahun, "Technology Acquisition," Module for Technology Transfer 
Management Course, pp. 143-197.

Komet Mangiri, 2000, Perencanaan Terpadu Pembangunan Ekonomi Daerah

Otonom, Badan Pusat Statistik, Jakarta. 